\title{
Table of requests for consultations citing protocol of accession provisions
}

DS532, Russia - Measures Concerning the Importation and Transit of

Certain Ukrainian Products (Complainant: Ukraine), 13 October 2017

DS525/1, Ukraine - Measures relating to Trade in Goods and Services,

1 June 2017

DS525, Ukraine - Measures relating to Trade in Goods and Services

(Complainant: Russian Federation), 19 May 2017

DS517, China - Tariff Rate Quotas for Certain Agricultural Products

(Complainant: United States), 15 December 2016

DS516, European Union - Measures Related to Price Comparison

Methodologies (Complainant: China), 12 December 2016

DS515, United States - Measures Related to Price Comparison

Methodologies (Complainant: China), 12 December 2016

DS512, Russian Federation - Measures Concerning Traffic in Transit

(Complainant: Ukraine), 14 September 2016

DS509, China - Duties and other Measures concerning the Exportation of

Certain Raw Materials (Complainant: European Union),

19 July 2016

DS508, China - Export Duties on Certain Raw Materials (Complainant:

United States), 13 July 2016

DS501, China - Tax Measures Concerning Certain Domestically Produced

Aircraft (Complainant: United States), 8 December 2015

DS451, China - Measures Relating to the Production and Exportation of

Apparel and Textile Products (Complainant: Mexico), 15 October 2012

DS450, China - Certain Measures Affecting the Automobile and

Automobile-Parts Industries (Complainant: United States),

17 September 2012

DS437, United States - Countervailing Duty Measures on Certain Products

from China (Complainant: China), 25 May 2012

DS433, China - Measures Related to the Exportation of Rare Earths,

Tungsten and Molybdenum (Complainant: Japan), 13 March 2012

DS432, China - Measures Related to the Exportation of Rare Earths,

Tungsten and Molybdenum (Complainant: European Union),

13 March 2012

DS431, China - Measures Related to the Exportation of Rare Earths,

Tungsten and Molybdenum (Complainant: United States), 13 March

2012 
DS429, United States - Anti-Dumping Measures on Certain Shrimp from Viet Nam (Complainant: Viet Nam), 27 February 2012

DS419, China - Measures concerning Wind Power Equipment (Complainant:

United States), 22 December 2010

DS405, European Union - Anti-Dumping Measures on Certain Footwear from China (Complainant: China), 4 February 2010

DS404, United States - Anti-Dumping Measures on Certain Shrimp from Viet Nam (Complainant: Viet Nam), 1 February 2010

DS399, United States - Measures Affecting Imports of Certain Passenger Vehicle and Light Truck Tyres from China (Complainant: China), 14 September 2009

DS398, China - Measures Related to the Exportation of Various Raw Materials (Complainant: Mexico), 21 August 2009

DS397, European Communities - Definitive Anti-Dumping Measures on Certain Iron or Steel Fasteners from China (Complainant: China), 31 July 2009

DS395, China - Measures Related to the Exportation of Various Raw Materials (Complainant: European Communities), 23 June 2009

DS394, China - Measures Related to the Exportation of Various Raw Materials (Complainant: United States), 23 June 2009

DS390, China - Grants, Loans and Other Incentives (Complainant: Guatemala), 19 January 2009

DS388, China - Grants, Loans and Other Incentives (Complainant: Mexico), 19 December 2008

DS387, China - Grants, Loans and Other Incentives (Complainant: United States), 19 December 2008

DS379, United States - Definitive Anti-Dumping and Countervailing Duties on Certain Products from China (Complainant: China), 19 September 2008

DS378, China - Measures Affecting Financial Information Services and Foreign Financial Information Suppliers (Complainant: Canada), 20 June 2008

DS373, China - Measures Affecting Financial Information Services and Foreign Financial Information Suppliers (Complainant: United States), 3 March 2008

DS363, China - Measures Affecting Trading Rights and Distribution Services for Certain Publications and Audiovisual Entertainment Products (Complainant: United States), 10 April 2007

DS359, China - Certain Measures Granting Refunds, Reductions or Exemptions from Taxes and Other Payments (Complainant: Mexico), 26 February 2007

DS358, China - Certain Measures Granting Refunds, Reductions or Exemptions from Taxes and Other Payments (Complainant: United States), 2 February 2007

DS342, China - Measures Affecting Imports of Automobile Parts

(Complainant: Canada), 13 April 2006

DS340, China - Measures Affecting Imports of Automobile Parts

(Complainant: United States), 30 March 2006 
DS339, China - Measures Affecting Imports of Automobile Parts

(Complainant: European Communities), 30 March 2006 110,112

\section{EUROPEAN COURTS}

Court of Justice of the European Union (CJEU), European Commission v

Rusal ZAO (Case C-21/14 P) ............................................ 261, 262, 263

General Court, Rusal Armenal ZAO v Council of the European Union

(Case T-512/09) 2010/C 80/49 (21 December 2009) .............. 258, 259, 260 